\title{
Macronutrients and essential amino acids on the digestive process of the freshwater teleost matrinxã (Brycon amazonicus)
}

\author{
[Macronutrientes e aminoácidos essenciais no processo digestivo do teleósteo de água doce \\ matrinxã (Brycon amazonicus)]
}

\section{"Scientific Article/Artigo Científico"}

\author{
Rodrigo Yamakami Camilo ${ }^{1}$, Claucia Aparecida Honorato ${ }^{2 *}$, Rudã Fernandes Brandão Santos ${ }^{3}$, \\ Ive Marchioni Avilez ${ }^{4}$, Luciana Cristina de Almeida ${ }^{4}$, Gilberto Moraes ${ }^{4}$
}

\author{
${ }^{1}$ Instituto Federal de São Paulo, Câmpus Barretos, Barretos-SP, Brazil. \\ ${ }^{2}$ Faculdade de Ciências Agrárias, Universidade Federal da Grande Dourados, Dourados-MS, Brazil. \\ ${ }^{3}$ Departamento de Bioquímica, Universidade Federal de Pernambuco, Recife-PE, Brazil. \\ ${ }^{4}$ Departamento de Genética e Evolução, Universidade Federal de São Carlos, São Carlos-SP, Brazil. \\ *Corresponding author/Autora para correspondência: E-mail: clauciahonorato@yahoo.com.br
}

\begin{abstract}
The objective of this work was to evaluate the effect of macronutrients and essential amino acids on the digestive process of the freshwater teleost matrinxã (Brycon amazonicus). Juveniles were fed with diets containing starch plus free amino acids or oil plus free amino acids for 15 days. These fish were compared with others fed with diets containing starch or oil without addition of free amino acids. After the experimental span, 12 fish from each treatment were randomly sampled to collect stomach, pyloric cecum, anterior and posterior intestine for assaying digestive enzymes activity. Increase of gastric proteolysis due to dietary amino acids were observed. Amylolytic, proteolytic and lipolytic activities in intestine sections were also positive due to dietary amino acids. However, proteolytic and lipolytic activities in pyloric cecum were not responsive to dietary changes. Moreover, the absence of starch in the diets resulted in decrease of amylolysis, and very low levels of oil did not change the lipolytic activity. Based on the results of the present study, the inclusion of essential amino acids in diets for juvenile matrinxã promotes a nutrition strategy to improve digestive function.
\end{abstract}

Keywords: Brycon amazonicus; dietary amino acids; digestive enzymes; enzyme regulation; nutrition.

\begin{abstract}
Resumo
O objetivo deste trabalho foi avaliar o efeito de macronutrientes e de aminoácidos essenciais no processo digestivo do teleósteo de água doce matrinxã (Brycon amazonicus). Os peixes foram alimentados com dietas contendo amido e aminoácidos livres ou óleo e aminoácidos livres por 15 dias. Após o período experimental, 12 peixes de cada tratamento foram amostrados aleatoriamente para coletar estômago, ceco pilórico, intestino anterior e posterior para avaliar a atividade das enzimas digestivas. Observou-se o aumento da proteólise gástrica pela presença de aminoácidos da dieta. Atividades amilolíticas, proteolíticas e lipolíticas em seções do intestino também foram positivas em relação aos aminoácidos da dieta. No entanto, as atividades proteolíticas e lipolíticas no ceco pilórico não foram responsivas às mudanças na dieta. Além disso, a ausência de amido nas dietas resultou em diminuição da amilólise, e níveis muito baixos de óleo não alteraram a atividade lipolítica. Com base nos resultados do presente estudo, a inclusão de aminoácidos essenciais em dietas para juvenis de matrinxã promove uma estratégia nutricional para melhorar a função digestiva.
\end{abstract}

Palavras-chave: Brycon amazonicus; aminoácidos da dieta; enzimas digestivas; regulação enzimática; nutrição. 


\section{Introduction}

Improvements in fish production are related to progress in nutrition techniques and in the role of chemical and physical factors which interfere in the best use of nutrients by the fish. The feeding of fish in the farms must be done with strict protocols either for commercial reasons or to prevent environmental damages. The food nutritional value depends basically on factors such as the diet composition, the animal capacity of digestion and absorption and environmental factors (Abidi and Khan, 2011).

A limiting factor in the food conversion of fish is the availability of digestive enzymes in the gastrointestinal tract (Pujante et al., 2017). The effect of the macronutrients content on the production and or secretion of digestive enzymes have been widely reported in fish (Corrêa et al., 2007; Honorato et al., 2016). Small biomolecules can also affect the production of digestive enzymes (Xiao et al., 2011). Polypeptides and amino acids from protein digestion can modulate the pancreatic proteases production, particularly trypsin (Zambonino Infante and Cahu, 2007).

Factors required to enhance the enzymatic efficiency of digestive processes have been investigated by researchers who aims to optimize production and activity of digestive enzymes, as well as the best fulfilling of nutritional demands (Dabrowski et al., 2007; Yamashiro et al., 2016; Neu et al., 2017; Alami-Durante et al., 2020).

In this perspective it is interesting to study the species, matrinxã (Brycon amazonicus) is a freshwater teleost widely farmed in South America (Arbeláez-Rojas and Moraes, 2009). This omnivorous fish species accepts a large range of artificial food pellets and is becoming a good subject to nutritional studies (Frasca-Scorvo et al., 2007). Its ability to respond to nutritional changes (Zambonino Infante and Cahu, 2007) raised the possibility of optimizing the nutrient composition of diets exploring the regulatory mechanisms involved in it. It is known that lipids and starch are usually effective on lipase and amylase expression (Abidi and Khan, 2011).

The objective of this work was to evaluate the effect of macronutrients and essential amino acids on digestive process of the freshwater teleost matrinxã (Brycon amazonicus).

\section{Materials and Methods}

Juvenile fish matrinxã from the same strain were acclimated for 10 days in 2,000 L tanks of a flow-through system and fed to satiety twice a day with commercial pellets containing 35\% crude protein $(\mathrm{CP})$ at the Department of Genetics and Evolution, Federal University of São Carlos (UFSCar). One-hundred-sixty-two acclimated fish, ranging $94 \pm 20 \mathrm{~g}$ and $18.5 \pm 2 \mathrm{~cm}$, were equally divided into 18 tanks (experimental unities) of 250 $\mathrm{L}$ with the same water conditions (temperature $25 \pm 1{ }^{\circ} \mathrm{C}, \mathrm{pH} 7.2$, dissolved oxygen $5.4 \mathrm{mg} \mathrm{L}^{-1}$, alkalinity $42 \mathrm{mg} \mathrm{L}^{-1}$, ammonia $0.12 \mathrm{mg} \mathrm{L}^{-1}$ ).

Six experimental unities (treatments) were randomly assigned as: $\mathrm{F}$ (fasting); $\mathrm{C}$ (control diet: oil plus starch plus essential amino acids); S (diet with starch); S-AA (diets $\mathrm{S}$ plus essential amino acids); O (diet with oil); O-AA (diet O plus essential amino acids). The essential amino acids chosen were arginine, histidine, tryptophan, phenylalanine, leucine and valine and were added in the amount of $1 \mathrm{~g} \mathrm{~kg}^{-1}$ in the diets (Abidi and Khan, 2011). The composition of the diets is showed in Table 1. The ingredients were mixed with $500 \mathrm{ml}$ of water per $\mathrm{kg}$ of diet, processed to 4 $\mathrm{mm}$ pellets and dried at $55 \pm 1^{\circ} \mathrm{C}$ for 3 days. The diets were packed and kept at $-20^{\circ} \mathrm{C}$ in black packs.

The fish were fed with the experimental diets twice a day until satiety for 20 days and the feeding was discontinued 24 hours before sampling. No fish died over the experimental period. Four fish from each tank (12 per treatment) were randomly sampled at the end of the experimental span, anaesthetized with $60 \mathrm{mg} \mathrm{L}^{-1}$ eugenol and euthanized by medullar section. Digestive tract was excised, divided into stomach, pyloric cecum, anterior intestine and posterior intestine. The sections were quickly frozen into liquid nitrogen and transferred to $-20^{\circ} \mathrm{C}$ for posterior enzyme assays (The committee on animal ethics protocol number 004/14).

The activity of the digestive enzymes in the gastrointestinal sections was assayed in tissue homogenates. Tissue samples were there to homogenized at a 1:10 ratio (tissue: phosphate buffer- $20 \mathrm{mM}$ sodium phosphate $/ 10 \mathrm{mM}$ Trisbuffer water solution at $\mathrm{pH} 7.0$, diluted in glycerolwater 1:1). Tissues were disrupted with a motor Teflon pestle at $112 \times \mathrm{g}$ for 1 minute under icebath. The cell homogenates were centrifuged at $13,400 \times g$ for 3 minutes. Supernatants, previously adjusted to the optimal protein amount, were used as crude enzyme source. All the samples were assayed in duplicate and two blanks were used: the non-enzymatically hydrolysed substrate reaction (enzyme blank) and the endogenous substrate 
reaction (substrate blank). Enzyme specific activities were calculated regarding the protein content of enzyme homogenates. Protein concentration was determined according to Bradford et al. (1976) in tissue homogenate samples using bovine serum albumin solution
Sigma-Aldrich Chemical Co. (St Louis, MO, USA) as standard and the reagent of Bradford (Bradford et al., 1976). One enzyme unit (1 UI) was considered as $1 \mu \mathrm{mol}$ of substrate was hydrolysed (or product was formed) per min, and it was expressed per mg of protein (UI mg-1 protein).

Table 1. Ingredients and estimated composition of the experimental diets (dry matter basis)

\begin{tabular}{|c|c|c|c|c|c|}
\hline \multirow[b]{2}{*}{ Ingredient $\left(\mathrm{g} \mathrm{kg}^{-1}\right)$} & \multicolumn{5}{|c|}{ Experimental diets } \\
\hline & Control & $\mathrm{S}$ & S-AA & $\mathrm{O}$ & $\mathrm{O}-\mathrm{AA}$ \\
\hline Casein & 250.0 & 250.0 & 250.0 & 250.0 & 250.0 \\
\hline Gelatin & 100.0 & 100.0 & 100.0 & 100.0 & 100.0 \\
\hline Cellulose & 200.0 & 266.0 & 260.0 & 555.0 & 5490 \\
\hline Soy oil & 80.0 & - & - & 80.0 & 80.0 \\
\hline Starch & 349.0 & 369.0 & 369.0 & - & - \\
\hline Vitamin-mineral premix & 15.0 & 15.0 & 15.0 & 15.0 & 15.0 \\
\hline Arginine & 1.0 & - & 1.0 & - & 1.0 \\
\hline Histidine & 1.0 & - & 1.0 & - & 1.0 \\
\hline Tryptophan & 1.0 & - & 1.0 & - & 1.0 \\
\hline Phenylalanine & 1.0 & - & 1.0 & - & 1.0 \\
\hline Leucine & 1.0 & - & 1.0 & - & 1.0 \\
\hline Valine & 1.0 & - & 1.0 & - & 1.0 \\
\hline \multicolumn{6}{|l|}{ Chemical composition } \\
\hline Dry matter ${ }^{3}$ & 927.6 & 921.6 & 923.8 & 942.7 & 946.3 \\
\hline Crude protein ${ }^{3}$ & 363.0 & 359.0 & 364.5 & 349.5 & 353.5 \\
\hline Crude fiber ${ }^{3}$ & 107.1 & 119.8 & 111.9 & 334.2 & 329.6 \\
\hline $\operatorname{Ash}^{3}$ & 10.5 & 9.1 & 9.0 & 7.0 & 9.7 \\
\hline Crude lipid $^{3}$ & 107.1 & 4.0 & 2.2 & 86.8 & 97.9 \\
\hline $\mathrm{NFE}^{3 \mathrm{~A}}$ & 339.9 & 429.7 & 436.2 & 165.2 & 155.6 \\
\hline Gross energy $\left(\mathrm{kcal} \mathrm{kg}^{-1}\right)$ & 4670,41 & 4290,95 & 4297,83 & 4791,285 & 4845,49 \\
\hline \multicolumn{6}{|c|}{$\begin{array}{l}\text { 15 Sodium carboxymethylcellulose USP. Labsynth Products for Laboratory Ltda (Diadema-SP-Brazil). } \\
\text { 2 Composition of supplement vitamin-mineral fish (Fri-Ribe) premix, } 1000 \mathrm{~g} \text { : vitamin A, } 600000 \mathrm{IU} \text {; vitamin D3, } 600000 \mathrm{IU} \text {; vitamin } \\
\text { E, } 12000 \mathrm{IU} \text {; vitamin K3, } 1200 \mathrm{mg} \text {; vitamin B1, } 1200 \mathrm{mg} \text {; vitamin B2, } 1536 \mathrm{mg} \text {; vitamin B6, } 1287 \mathrm{mg} \text {; vitamin B12, } 4000 \mathrm{mg} \text {; folate, } \\
198 \mathrm{mg} \text {; calcium pantothenate, } 3800 \mathrm{mg} \text {; vitamin C, } 48000 \mathrm{mg} \text {; Biotin, } 20 \mathrm{mg} \text {; Choline, } 30000 \mathrm{mg} \text {; Niacin, } 19800 \mathrm{mg} \text {; Iron, } 25714 \\
\mathrm{mg} \text {; Copper, (Cu) } 1960 \mathrm{mg} \text {; Manganese, } 13334 \mathrm{mg} \text { Z Zinc, } 6000 \mathrm{mg} \text {; Iodine, } 948 \mathrm{mg} \text {; Cobalt, } 2 \mathrm{mg} \text {; Selenium, } 30.10 \mathrm{mg} \text {. } \\
{ }^{3} \text { Expressed in g kg-1 } \\
\text { C (control diet: oil plus starch plus essential amino acids); S (diet with starch); S-AA (diets S plus essential amino acids); O (diet with } \\
\text { oil); O-AA (diet O plus essential amino acids). }\end{array}$} \\
\hline
\end{tabular}

Amylase of pyloric cecum, anterior and posterior intestine was assayed in $0.2 \mathrm{M}$ citrate/phosphate buffer $\mathrm{pH} 7.0$ with $5 \%$ starch solution, $0.5 \% \mathrm{NaCl}$ as cofactor and adjusted aliquots of crude homogenate (Bernfeld, 1955). The enzyme reaction was performed at $25{ }^{\circ} \mathrm{C}$ for 30 minutes, stopped by addition of $\mathrm{Ba}^{2+}$ $\mathrm{Zn}^{2+}$ solution to a final concentration of $5 \% \mathrm{ZnSO}_{4}$ and $0.3 \mathrm{~N} \mathrm{Ba}(\mathrm{OH})_{2}$, and centrifuged at $1,000 \times \mathrm{g}$ for $3 \mathrm{~min}$. The reducing sugars produced were measured at $690 \mathrm{~nm}$ following the method of Park and Johnson (1949). Non-specific proteolytic activity was assayed in $1 \%$ casein as substrate (Walter, 1984). The $\mathrm{pH}$ values were previously optimized for intestine: $0.1 \mathrm{M}$ Tris- $\mathrm{HCl}$ buffer $\mathrm{pH}$ 8.0, and stomach: $0.2 \mathrm{M}$ glycine- $\mathrm{HCl} \mathrm{pH} 2.0$. Reactions were carried out at $25 \pm 1^{\circ} \mathrm{C}$ for $30 \mathrm{~min}$ (stomach) or $60 \mathrm{~min}$ (intestine), stopped with $15 \%$ TCA, kept at $4{ }^{\circ} \mathrm{C}$ for $1 \mathrm{~h}$, centrifuged at $14,400 \times$ $\mathrm{g}$ for $10 \mathrm{~min}$ and the supernatant absorbance was recorded at $280 \mathrm{~nm}$ against tyrosine standard solution. Trypsin of pyloric cecum, anterior and 
posterior intestine was assayed in $1.04 \mathrm{mM} \mathrm{N \alpha -p-}$ tosyl-1-arginine methyl ester-hydrochloride (Tame), $0.01 \mathrm{M} \mathrm{CaCl} 2 / 0.2 \mathrm{M}$, Tris/ $\mathrm{HCl}$ buffer at $\mathrm{pH} 8.1$, by addition of proper aliquots of crude homogenate and followed at $247 \mathrm{~nm}$ for 2 min at $25^{\circ} \mathrm{C}$ (Hummel, 1959). Lipase was assayed through $p$-nitrophenyl myristate hydrolysis (Albro et al., 1985). Reaction mixture was incubated at 25 ${ }^{\circ} \mathrm{C}$ for 30 minutes (pyloric cecum) or 45 minutes (anterior and posterior intestine) with $0.4 \mathrm{mM} \mathrm{p}$ nitrophenyl myristate in $24 \mathrm{mM}$ ammonium bicarbonate $(\mathrm{pH} 7.8)$ and $10.5 \%$ Triton $\mathrm{X}-100$. The reaction was stopped by adding $\mathrm{NaOH}$ to a final concentration of $10 \mathrm{mM}$ and the optical density was read at $405 \mathrm{~nm}$.

The trial performance considered five treatments in three replicates. The experiment was carried out in a randomized block design with three replicates $(n=12)$. Differences among enzymes activities from each feeding condition were evaluated by Anova One-Way accepted the confidence interval $95 \%$. When significant differences were observed among treatments the multiple comparisons test type Tukey was performed.

\section{Results and Discussion}

In the present study, the gastrointestinal tract of matrinxã was enzyme-responsive to dietary changes (Table 2) and digestive enzymes of matrinxã kept under fasting were not considerably reduced.

Table 2. Digestive enzymes activities of different gastrointestinal tract sections of matrinxã (Brycon amazonicus).

\begin{tabular}{|c|c|c|c|c|c|c|}
\hline \multirow[b]{2}{*}{ Amylase } & \multicolumn{6}{|c|}{ Treatment } \\
\hline & Fasting & Control & $\mathrm{S}$ & S-AA & $\mathrm{O}$ & $\mathrm{O}-\mathrm{AA}$ \\
\hline Cecum & $2.36 \pm 0.9 \mathrm{~b}$ & $14.73 \pm 2.6 \mathrm{a}$ & $14.33 \pm 2.9 \mathrm{a}$ & $12.64 \pm 1.4 \mathrm{a}$ & $2.30 \pm 0.9 \mathrm{~b}$ & $2.72 \pm 0.5 b$ \\
\hline Anterior intestine & $2.39 \pm 0.7 b$ & $5.73 \pm 1.1 \mathrm{a}$ & $4.83 \pm 0.7 \mathrm{a}$ & $5.90 \pm 0.6 \mathrm{a}$ & $0.83 \pm 0.1 \mathrm{c}$ & $0.90 \pm 0.1 \mathrm{c}$ \\
\hline Posterior intestine & $0.50 \pm 0.2 \mathrm{c}$ & $5.00 \pm 0.5 \mathrm{a}$ & $4.00 \pm 0.4 b$ & $4.90 \pm 0.4 \mathrm{a} \ddagger$ & $0.50 \pm 0.1 \mathrm{c}$ & $1.00 \pm 0.2 b t$ \\
\hline \multicolumn{7}{|l|}{ Unspecific Protease } \\
\hline Stomach & $2.2 \pm 1 \mathrm{~d}$ & $265.7 \pm 28 \mathrm{a}$ & $209.1 \pm 23 b$ & $312.8 \pm 59 \mathrm{a} t$ & $159.4 \pm 54 b c$ & $139.4 \pm 40 \mathrm{c}$ \\
\hline Cecum & $29.9 \pm 9 b$ & $110.8 \pm 10 \mathrm{a}$ & $118.8 \pm 16 a$ & $108.8 \pm 10 \mathrm{a}$ & $121.7 \pm 18 \mathrm{a}$ & $126.6 \pm 9 \mathrm{a}$ \\
\hline Anterior intestine & $0.6 \pm 0.5 \mathrm{c}$ & $5.3 \pm 1.0 \mathrm{a}$ & $5.3 \pm 1.0 \mathrm{a}$ & $4.8 \pm 1.0 \mathrm{a}$ & $3.6 \pm 0.3 b$ & $5.7 \pm 0.7 \mathrm{a} t$ \\
\hline Posterior intestine & $2.1 \pm 0.3 \mathrm{c}$ & $35.3 \pm 10.0 \mathrm{a}$ & $29.6 \pm 9.1 \mathrm{a}$ & $34.9 \pm 7.7 \mathrm{a}$ & $12.0 \pm 2.6 b$ & $27.8 \pm 5.3 a t$ \\
\hline \multicolumn{7}{|l|}{ Trypsin } \\
\hline Cecum & $0.72 \pm 0.3 b$ & $2.29 \pm 0.5 \mathrm{a}$ & $2.83 \pm 0.6 \mathrm{a}$ & $2.32 \pm 0.6 \mathrm{a}$ & $2.68 \pm 0.4 \mathrm{a}$ & $2.45 \pm 0.6 \mathrm{a}$ \\
\hline Anterior intestine & $0.04 \pm 0.0 \mathrm{c}$ & $0.15 \pm 0.0 \mathrm{a}$ & $0.16 \pm 0.0 \mathrm{a}$ & $0.15 \pm 0.0 \mathrm{a}$ & $0.11 \pm 0.0 \mathrm{~b}$ & $0.15 \pm 0.0 \mathrm{a} t$ \\
\hline Posterior intestine & $0.07 \pm 0.0 \mathrm{~d}$ & $1.24 \pm 0.3 \mathrm{a}$ & $1.27 \pm 0.2 \mathrm{a}$ & $1.14 \pm 0.2 \mathrm{a}$ & $0.18 \pm 0.0 \mathrm{c}$ & $0.48 \pm 0.0 \mathrm{~b} \ddagger$ \\
\hline \multicolumn{7}{|l|}{ Lipase } \\
\hline Cecum & 0 & $1.77 \pm 0.5 \mathrm{a}$ & $1.54 \pm 0.7 \mathrm{a}$ & $2.29 \pm 0.5 \mathrm{a}$ & $2.27 \pm 0.8 \mathrm{a}$ & $3.4 \pm 0.5 \mathrm{a}$ \\
\hline Anterior intestine & $0.93 \pm 0.5 \mathrm{c}$ & $5.74 \pm 0.5 b$ & $6.68 \pm 0.8 \mathrm{ab}$ & $8.09 \pm 0.7 \mathrm{a}$ & $5.32 \pm 0.8 b$ & $5.40 \pm 1.0 \mathrm{~b}$ \\
\hline Posterior intestine & $0.14 \pm 0.0 \mathrm{~d}$ & $0.71 \pm 0.3 b$ & $0.43 \pm 0.1 \mathrm{c}$ & $0.77 \pm 0.2 b t$ & $1.51 \pm 0.2 \mathrm{a}$ & $1.43 \pm 0.21 \mathrm{a}$ \\
\hline
\end{tabular}

S- fish fed diets with starch; S-AA- fish fed diets with starch plus essential amino acids; O- fish fed diets with oil; O-AA- fish fed diets with oil plus essential amino acids. Enzymes activities are expressed in U.mg protein ${ }^{-1}$. Values are expressed as mean \pm SD; ( significant increase due to essential amino acids addition. Different superscript letters in the same row means statistical differences at $\mathrm{p}<0.05$.

Concerning to protein digestion, the unspecific proteolytic activity was observed over all digestive tract of fish (Figure 1A). The stomach of matrinxã submitted to fasting displayed the lowest unspecific protease activity followed by fish from the treatments $\mathrm{O}+\mathrm{AA}, \mathrm{O}$ and $\mathrm{S}$. The stomach of fish fed with the diets $\mathrm{C}$ and S+AA showed increase of that enzyme activity. In the pyloric 
cecum, the fasting treatment caused reduction of unspecific protease and trypsin activities, but fish fed with the other treatments did not present any difference in these enzymes activities. The anterior and posterior intestine of matrinxã submitted to fasting exhibited the lowest activities of unspecific protease and trypsin (Figure 1B). This frame was followed by fish from the treatment $\mathrm{O}$. The anterior intestine of fish fed with the diets O+AA showed increased activities of non-specific proteases and trypsin. There was a straight correlation $(\mathrm{p}=0.82)$ between the non-specific protease and the trypsin activities which makes suppose that the main intestinal proteolytic activities in matrinxã are trypsin-like.

The relevance of proteins in the animal diets is brought out by the protease expression in the digestive tract. This kind of response observed in catfish (Rhamdia quelen) suggests that this enzyme ensures a plentiful utilization of the ingested protein (Melo et al., 2012). The source of protein, either animal or vegetal, may influence the yield of digestive processes in fish (Corrêa et al., 2007; Honorato et al., 2016). This fact was particularly observed in matrinxã. The stomach and pyloric cecum played a relevant role wherein nearly $90 \%$ of the proteolytic activities are expressed. This is inferred from the non-specific proteolytic activities which can consist of some distinct proteases. This is likely why these activities were responsive in the stomach, but steady in the pyloric cecum (Honorato et al., 2016). Invariable activities of non-specific proteases in the cecum emphasize the constitutive trait of such proteases and the relevance of protein digestion in this gut section.

The importance of such digestive characteristic explains the remarkable proteolytic activity in the pyloric cecum even after a long fastperiod. The ability of fish species to process foods depends on the digestive enzyme profile, the adaptive enzyme responses to nutrient levels (De Almeida et al., 2006) and the dietary chemical composition (Klomklao et al., 2009).

However, the high levels of proteolytic activity in the posterior intestine of matrinxã bring out the role of this gastrointestinal section to the protein digestion process in this species. Proteolytic activities in the posterior intestine of matrinxã, amazingly higher than that observed in anterior intestine, was likely to increase the absorption efficiency in the last digestive steps. These results can be attributed to supplement of amino acids the diets. Some authors reported different tendency of growth of fish or shrimp with the increase in dietary supplements for amino acid (Abidi and Khan, 2011).

The similar profiles of trypsin and nonspecific proteases observed between the pyloric cecum and intestine of matrinxã is suggestive that trypsin is the main proteolytic activity. Trypsin is reported in cecum of several fish species (Jiang et al., 2014). In the present study, the supply of food was remarkably effective on the trypsin activity in all digestive tract; however the factor involved in its secretion are likely distinct among the species. Probably, some iso-forms of trypsin in the intestine of matrinxã are nutrient responsive, distinctly of that isoform in the cecum. In Skipjack tuna (Katsuwonus pelamis) was observed in the gut two isoforms of trypsin with different biochemical properties (Klomklao et al., 2009).

Proteases of stomach were responsive to free essential amino acids in the presence of starch. The content of starch was crucial to up regulate proteases free amino acids were associated; under lower levels of starch, the free amino acids did not influence the protease expression, as observed in the fish fed with free starch diets. Furthermore, the release of gastrin is dependent on substances such as calcium, glucose and amino acids as phenylalanine and tryptophan (Nuche-Berenguer et al., 2015).

Therefore, the continuous presence of glucose sources plus amino acids should be responsible for stimulating the growth of gastric mucosa and, consequently, increasing the protease levels in matrinxã. Results suggest that $C$. quadricarinatus can modify hepatopancreatic enzyme levels in response to different compouds in the diet and can digest a broad variety of ingredients, particularly starch (López-López et al., 2005). The effect of free essential amino acids in the up regulation of proteases in the intestine of matrinxã was evident as starch was supplemented to the diets. Considering the relevance of proteolytic activity in this gastrointestinal section, as discussed above, the presence of amino acids is relevant to enhance the digestion and likely absorption of nutrients.

Differently of the pyloric cecum trypsin, the intestinal one was responsive to amino acids, as observed for non-specific proteases. This profile corroborates the assumption above that trypsin is probably the main proteolytic component of the non-specific proteases of matrinxã. Possibly this result can be attributed to the fact that presence of 
amino acids receptors is proposed in duodenum, jejunum and venous hepatic portal system (Nijima, 2000). It is hypothesized that due to their high tolerance of amino acid imbalances, fish are the ideal model organism to reexamine metabolic responses to dietary disproportions of amino acids (Dabrowski et al., 2007). Apparently the neurological responses of fish do not alter dietary intake, which can lead to efficient metabolic adjustments to optimize nutrient absorption (Dabrowski et al., 2007; Adel et al., 2017; Mansano et al., 2020).

These receptors should be able to stimulate the synthesis of digestive enzymes. Furthermore, the dietary amino acids should be directly involved in the stimulatory processes of synthesis and secretion of digestive enzymes. This hormone along with neural stimuli plays an important role in the secretion of digestive enzymes from pancreas (Nuche-Berenguer et al., 2015).

Carbohydrates were potentially hydrolysed in all sections of matrinxã intestine (Figure 1C). The highest amylase activity was observed in the pyloric cecum, and fish submitted to fasting and to the treatments $\mathrm{O}$ and $\mathrm{O}+\mathrm{AA}$ presented a decrease of amylase activity as compared with fish submitted to the others treatments. However, in the anterior intestine the amylase activity of fish from treatments $\mathrm{O}$ and $\mathrm{O}+\mathrm{AA}$ was lower than that in fish submitted to fasting. Posterior intestine of fish fed with the diets O+AA depicted increase of amylase as compared with fish from fasting condition or from treatment $\mathrm{O}$. The posterior intestine of fish fed with control and S+AA diets showed the highest amylase activities.

The presence of amylase over the all intestine is a factual indicative of the species ability to utilize carbohydrates, and opens the perspective of optimizing their dietary levels to spare protein. This trait is usual in several fish species, particularly in omnivorous freshwater fishes (Honorato et al., 2016). Pyloric cecum is the most efficient section to digest starch in B. amazonicus, and the remarkable decrease of amylase in fish fed with diets with oil was like due to the starch deficiency.

The presence of essential amino acids in the diets increased the amylase activity in the posterior intestine and this section showed high levels of amylase when fish were fed with S+AA (Figure 1C). Glucose, released from starch hydrolysis, likely plays important role in the amylase upregulation and this fact should mask positive enzyme induction caused by free essential amino acids. Glucose is supposed more abundant when starch was increased in the feeding (Honorato et al., 2016). The effect of glucose on the pancreatic tissue is well known. Glucose stimulates the release of insulin which stimulates production and release of amylase (Nuche-Berenguer et al., 2015). The increase of non-protein, digestible energy enhances the nitrogen retention (Perera and Simon, 2014). Therefore, there is a faint edge to be established between the dietary carbohydrate and the offering of amino acids toward the optimization of amylase productions and the best use of carbohydrates and proteins.

Lipolytic activity was observed in all intestinal sections of matrinxã (Figure 1D). The highest activities were observed in the anterior intestine followed by the pyloric cecum, where in it was independent of the dietary composition and dropped to nil when the fish were submitted to fasting. The fish fed with the diets S+AA displayed increase of the lipase activity. The lipase activity in the posterior intestine section was higher when oil was added to diet.

Considering the discrepant levels of dietary lipid used in this work (presence or absence) and the relatively steady activities of lipase in every section, it is plausible to assume that this is a low dietary-responsive enzyme in $B$. amazonicus. Lipase activity in matrinxã was just reported as adaptive to the deal of lipid present in the intestinal content (Melo et al., 2012). This fact was further explored in the present work and the cecum was shown to be unresponsive. However, to some extent responsiveness was observed in the intestine. Therein, it seems that distinct lipases are expressed; one, in the proximal intestine, which is regulated by starch along with amino acids, and the other, in the posterior intestine, regulated by luminal lipids. The anterior intestine of matrinxã is likely the most relevant section in the lipid digestion, either due to adaptive character or to lipase activity.

However, a conclusive statement on the role of digestive lipases must be linked to lipid digestibility. A positive correlation between lipase activity and lipid digestibility was reported in fish (Perera and Simon, 2014). 

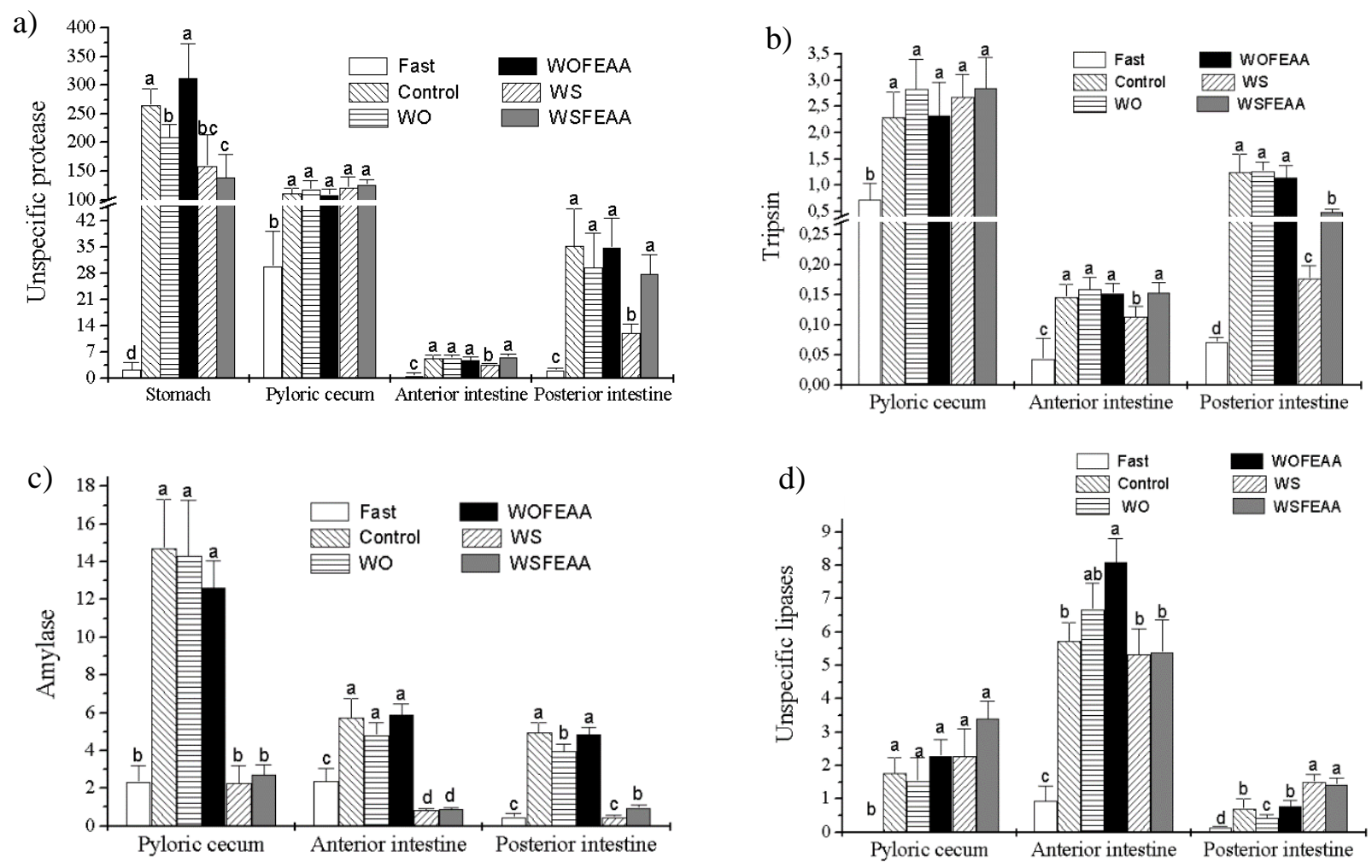

Figure 1. Enzymes activity of stomach, pyloric cecum, anterior intestine and posterior intestine of matrinxã (Brycon amazonicus) in $\mathrm{U}$ mg of protein ${ }^{-1}$ : a) amylase, b) unspecific protease, c) trypsin and d) unspecific lipases. The fish were in sin different alimentary conditions: Fast; Control; without oil (WO); without oil plus free essential amino acids (WOFEAA); without starch (WS); without starch plus free essential amino acids (WSFEAA). Different letters in the same group of tissues mean statistical differences at $\mathrm{P}<0.05$. Values are mean $\pm \mathrm{SD}$ for $\mathrm{n}=12$ fish.

Supplemented diets with free essential amino acids are still a polemic and controversial subject. However, black bream (Megalobrama amblycephala) fed with diets supplemented with DL-methionine show improvements in the growth performance (Liao et al., 2014). Although controversies, the adjustment of macronutrients is crucial to optimize fish nutrition and growth performance (Honorato et al., 2016), and this is dependent on optimal combinations of nutrients. Improvements on formulation and confection of fish diets are a constant concern. In this particular, the feeding of matrinxã must take into account the presence of essential free amino acids in the diets to enhance the activities of digestive enzymes.

\section{Conclusion}

Based on the results of the present study, the inclusion of essential amino acids in diets for juvenile matrinxã promotes a nutrition strategy to improve digestive function.

\section{Conflict of interest}

The authors declare that there is no conflict of interest.

\section{Ethics Committee}

The assay has been approved by the Ethics Committee for Animals Use of University Center of Grande Dourados (Protocol number 39/16).

\section{Acknowledgments}

The authors thank the colleagues of the Laboratory of Adaptive Biochemistry for logistic support. This research was sponsored by FAPESP (Sao Paulo State Research Foundation) and CNPq (Brazilian Council of Research).

\section{References}

Abidi S.F.; Khan, M.A. Total sulphur amino acid requirement and cystine replacement value for fingerling rohu, Labeo rohita: effects on growth, nutrient retention and body composition. Aquaculture Nutrition, 17(2): 583-594, 2011.

Adel, M.; Gholaghaie, M.; Khanjany, P.; Citarasu, T. Effect of dietary soybean lecithin on growth parameters, digestive enzyme activity, antioxidative status and mucosal immune responses of common carp (Cyprinus carpio). Aquaculture Nutrition, 23: 1145-1152, 2017. 
Alami-Durante, H.; Cluzeaud, M.; Bazin, D.; Vachot, C.; Kaushik, S. Variable impacts of Larginine or L-NAME during early life on molecular and cellular markers of muscle growth mechanisms in rainbow trout. Comparative Biochemistry and Physiology Part A: Molecular and Integrative Physiology, 242: 1-12, 2020.

Albro, P.W.; Hall, R.D.; Corbett, J.T.; Schroeder, J. Activation of non-specific lipase (EC 3.1.1.) by bile salts. Biochimica et Biophysica Acta, 835(3): 477-490, 1985.

Arbeláez-Rojas, G.A.; Moraes, G. Interação do exercício de natação sustentada e da densidade de estocagem no desempenho e na composição corporal de juvenis de matrinxã Brycon amazonicus. Ciência Rural, 39(1): 201-208, 2009.

Bernfeld, P. Amylases, $\alpha$ and $\beta$. Methods Enzymology, 1: 149-158, 1955.

Bradford, M.M.; Mcrorie, R.A.; William, W.L. A rapid and sensitive method for the quantitation of microgram quantities of protein utilizing the principle of protein-dye binding. Analytical Biochemistry, 72(1-2): 248-254, 1976.

Corrêa, C.F.; Aguiar, L.H.; Lundstedt, L.M.; Moraes, G. Responses of digestive enzymes of tambaqui (Colossoma macropomum) to dietary cornstarch changes and metabolic inferences. Comparative Biochemistry and Physiology, 147(4): 857-862, 2007.

Dabrowski, K.; Arslan, M.; Terjesen, B.F.; Zhang, Y. The effect of dietary indispensable amino acid imbalances on feed intake: Is there a sensing of deficiency and neural signaling present in fish? Aquaculture, 268: 136-142, 2007.

De Almeida, L.C.; Lundstedt, L.M.; Moraes, G. Digestive enzyme responses of tambaqui (Colossoma macropomum) fed on different levels of protein and lipid. Aquaculture Nutrition, 12(6): 443-450, 2006.

Frasca-Scorvo, C.M.; Carneiro, D.J.; Malheiros, E.B. Efeito do manejo alimentar no desempenho do matrinxã Brycon amazonicus em tanques de cultivo Acta Amazonica, 37(4): 621-628, 2007.

Honorato, C.A.; De Almeida, L.C.; Camilo, R.Y.; Moraes, G.; Nunes, C.D.S.; Carneiro, D.J. Dietary carbohydrate and food processing affect the digestive physiology of Piaractus mesopotamicus. Aquaculture Nutrition, 22(4): 857-864, 2016.
Hummel, B.C.W. A modified spectrophotometric determination of chymotrypsin, trypsin and trombin. Canadian Journal of Biochemistry and Physiology, 37(12): 1393-1399, 1959.

Jiang, T.T.; Feng,L.. Liu, Y.; Jiang, W.D.; Jiang, J.; Li, S.H.; Tang, L.; Kuang, S.Y.; Zhou, X.Q. Effects of exogenous xylanase supplementation in plant protein-enriched diets on growth performance, intestinal enzyme activities and microflora of juvenile Jian carp (Cyprinus carpio var. Jian). Aquaculture Nutrition, 20(6): 632-645, 2014.

Klomklao, S.; Kishimura, H.; Nonami, Y.; Benjakul, S. Biochemical properties of two isoforms of trypsin purified from the intestine of skipjack tuna (Katsuwonus pelamis). Food Chemistry, 115(1): 155-162, 2009.

Liao, Y.J.; Ren, M.C.; Liu, B.; Sun, S.M.; Cui, H.H.; Xie, J.; Zhou, Q.L.; Pan, L.K.; Chen, R.L.; GE, X.P. Dietary methionine requirement of juvenile blunt snout bream (Megalobrama amblycephala) at a constant dietary cystine level. Aquaculture Nutrition, 20(6): 741-752, 2014.

López-López, S.; Nolasco, H.; VillarrealColmenares, H.; Civera-Cerecedo, R. Digestive enzymes response to supplemental ingredientes in practical diets for juvenile freshwater crayfish Cherax quadricarinatus. Aquaculture Nutrition, 11(2): 79-85, 2005.

Mansano, C.F.M.; do Nascimento, T.M.T.; Peres, H.; Rodrigues, F.H.F.; Khan, K.U.; Romaneli, R.S.; Sakomura, N.K.; Fernandes, J.B.K. Determination of the optimum dietary essential amino acid profile for growing phase of Nile tilapia by deletion method. Aquaculture, 523: 735204, 2020.

Melo, J.F.B.; Lundstedt, L.M.; Moraes, G.; Inoue, L.A.K.A. Effect of different concentrations of protein on the digestive system of juvenile silver catfish. Arquivo Brasileiro de Medicina Veterinária e Zootecnia, 64(2): 450-457, 2012.

Neu, D.H.; Boscolo, W.R.; De Almeida, F.L.A.; Zaminhan Hassemer, M.; Dallagnol, J.M.; Furuya, W.M. Desempenho produtivo, hematologia e crescimento muscular de tilápia do Nilo alimentadas com isoleucina. Boletim do Instituto de Pesca, 43: 231-242, 2017.

Nijima, A. Reflex effects of oral, gastrointestinal and hepatoportal glutamate sensors on vagal nerve activity. Journal Nutrition, 130(4): 971973, 2000. 
Nuche-Berenguer, B.; Moreno, P.; Jensen, R.T. Elucidation of the roles of the Src kinases in pancreatic acinar cell signaling. Journal of Cellular Biochemistry, 116(1): 22-36, 2015.

Park, J.T.; Johnson, M.J. A submicro determination of glucose. Journal of Biological Chemistry, 181(1): 140-151, 1949.

Perera, E.; Simon, C. Digestive physiology of spiny lobsters: implications for formulated diet development. Reviews in Aquaculture, 6(4): 1-19, 2014.

Pujante, I.M.; Díaz-López, M.; Mancera, J.M.; Moyano, F.J. Characterization of digestive enzymes protease and alpha-amylase activities in the thick-lipped grey mullet (Chelon labrosus, Risso 1827). Aquaculture Research, 48(2): 367-376, 2017.

Walter, H.E. Proteinases: methods with hemoglobin, casein and azocoll as substrates.
In: Methods of Enzymatic Analysis, Verlag Chemie, Weinheim, 1984. p. 270-277.

Xiao, W.W.; Feng, L.; Liu, Y.; Jiang, J.; Hu, K.; Jiang, W.D.; Li, S.H.; Zhou, X.Q. Effects of dietary methionine hydroxy analogue supplement on growth, protein deposition and intestinal enzymes activities of juvenile Jian carp (Cyprinus carpio var. Jian). Aquaculture Nutrition, 17(4): 408-417, 2011.

Yamashiro, D.; Neu, D.H.; Moro, E.B.; Feiden, A.; Signor, A.; Boscolo, W R.; Bittencourt, F. Performance and muscular development of Nile tilapia larvae (Oreochromis niloticus) fed increasing concentrations of phenylalanine. Agricultural Sciences, 7(12): 900-910, 2016.

Zambonino Infante, J.; Cahu, C.L. Dietary modulation of some digestive enzymes and metabolic processes in developing marine fish: applications to diet formulation. Aquaculture, 268(1-4): 98-105, 2007. 